\title{
A study on risk factors of cervical cancer among patients attending a tertiary care hospital: A case-control study
}

\author{
Pragati Sharma ${ }^{\mathrm{a}, *}$, Sanjay M. Pattanshetty ${ }^{\mathrm{b}, 1}$ \\ a Blavatnik School of Government, University of Oxford, United Kingdom \\ ${ }^{\mathrm{b}}$ School of Public Health, Manipal University, Karnataka, India
}

\section{A R T I C L E I N F O}

\section{Article history:}

Received 18 August 2017

Received in revised form 26 September 2017

Accepted 2 October 2017

Available online 3 October 2017

\section{Keywords:}

Cervical cancer

Parity

Abortion

Menarche

\begin{abstract}
A B S T R A C T
Background: Cancer is an important health issue. According to the WHO report, globally, cervical cancer comprises $12 \%$ of all cancers in women and it is the leading gynaecological malignancy in the world. In many developing countries, it is the most common cancer among women where $85 \%$ of the estimated 493 000 new cases and 273000 deaths in 2002 occurred worldwide.

Objectives: 1 . To study the association between cervical cancer and parity. 2 . To study the association between cervical cancer and other selected exposure variables

Settings and design: A hospital based case-control study was conducted in Shirdi Sai Baba Cancer Hospital and Research Centre, Manipal, Udupi District

Methods and material: A total of 273 participants (91 cases and 182 controls) were included. Information on demographics, habits, reproductive history, sexual history and menstrual history was taken using a semi-structured questionnaire. Statistical analysis used: Data was analysed using SPSS version 15. Univariate and Multivariate logistic regression was used to find out the association between the outcome and exposure variables. Results are expressed in odds ratio.

Results: Marital status (married) is an important risk factor for cervical cancer, OR=2.98 (1.23-7.20). People having history of alcohol use were at 4.55 (1.17-17.73) times at risk of developing cervical cancer when compared to those who did not use alcohol. Age at menarche of 13-14 years was found to be a significant risk factor of cervical cancer with OR of 2.91(1.18-7.20). Age at 1 st coitus of $<18$ years had an odds ratio of 5.44(2.73-6.38) and was significantly associated. At least one abortion is an important risk factor with odds of 2.61 (1.70-18.96). Also, adjusted odds ratio for parity of 3-5 was 3.16 (1.12-8.91) and 5.57 (1.70-18.96) for women having $\geq 6$ parity when compared to women having parity of less than 3 and was statistically significant.

Conclusions: The study showed that marital status, history of alcohol use, $<18$ years of age at first coitus, age at menarche and parity of $>3$ as risk factors of cervical cancer
\end{abstract}

(C) 2017 Published by Elsevier, a division of RELX India, Pvt. Ltd on behalf of INDIACLEN.

\section{Introduction}

Cancer is an important health issue across the world. Globally, it accounted for 11.4 million new cases and $13 \%$ of all deaths (11.4 million) deaths in 2004. ${ }^{1}$ Its incidence in SEAR in the year 2004 was 1.7 million. $^{2}$ Cancer has taken its place in top leading causes of death in India $^{3}$ of which cervical cancer accounts for $17 \%$ of all cancer deaths ${ }^{4}$. However, distribution of cancer sites varies in

\footnotetext{
* Corresponding author.

E-mail addresses: sprag06@gmail.com (P. Sharma), sanjay.pattanshetty@manipal.edu (S.M. Pattanshetty).

${ }^{1}$ Past affiliations: MD Community Medicine, Kasturba Medical College, Manipal University, Karnataka, India
}

different parts of the world with the developing world carrying the major burden. An estimated 2 to 2.5 million cases of cancer are present in India at any given point of time ${ }^{5}$ and one quarter of global cervical cancer burden is borne by India alone ${ }^{4}$. The estimates show that cervical cancer may occur in every $1 / 53$ women in developing countries as compared to 1/100 in developed region $^{4}$. In Karnataka, about 1.5 lakh cases are present as prevalent cases and approximately 35,000 new cases are added to this each year. $^{6}$ The consolidated report of cancer registries in South India reported stomach cancer for males and cervical cancer for females as the most common cancer sites. ${ }^{7-9}$ The age adjusted incidence of cervix cancer in urban India is $15-20$ new cases per 100,000 women per year. ${ }^{10}$ According to $\mathrm{WHO}$, in many developing countries, it is the most common cancer among women where $85 \%$ of the estimated 493000 new cases and 273000 deaths in 2002 
occurred worldwide. ${ }^{11}$ In a study carried out in 1967, the risk factors of cervical cancer such as early marriage and delivery, number of partners and deliveries were identified as higher risk factors for cervical cancer. ${ }^{12}$ Each cancer is unique and has various determinants; it differs from individual to individual and from one geographical location to the other. To my best knowledge, no riskfactor analysis has been carried out for cervical cancer in southern India- mainly in Udupi district. In past studies from across the world, personal hygiene, menstrual history and sexual history are shown to be associated with cervical cancer by some epidemiological studies done in different corners of world and India. ${ }^{12-28}$ The present study attempts to find out the various risk factors of cervical cancer among patients attending the tertiary care hospital - Shirdi Sai Baba Cancer Hospital, Manipal- in Udupi District.

\section{Subjects and methods}

\subsection{Ethics statement}

Ethical clearance was obtained from institutional ethics committee and hospital administration, Kasturba Medical College, Mnaipal University. The study participants were informed about the purpose, method and possible discomforts related with the questions and informed written consent was obtained.

\subsection{Inclusion and exclusion criteria}

All histopathologically confirmed cases of cervical cancer between the age group of 20-80 years were included in the study irrespective of their stages, and frequency matching for age \pm 5 years was done (the available age range in the cervical cancer register was taken as the study participants age range); patient other than cervical cancer in the hospital were selected as controls. Cases, which were not willing to participate in study or those cases that were seriously ill were excluded from the study. Controls with first degree relatives, having personal history of cervical cancer and reproductive tract infection, pregnant women, women with gynaecological problems were excluded from the study. The cases and controls were interviewed using a semi-structured questionnaire.

\subsection{Statistical methods}

Sample size was calculated considering a parity of $\geq 3$ (DLHS III) as a risk factor with an exposure of $20 \%$ in the control group and an anticipated OR of 2 for a power of $80 \%$ and 5\% level of significance. The calculated number of cases of cervical cancer was 91 . For 1:2 allocation ratios the required number of controls were 182 , hence 273 individuals were included in the study. Data analysis was done using statistical package for social sciences software. Data is summarized in form of tables. Univariate logistic regression analysis was used to evaluate the factors significantly associated with cervical cancer. Multiple Logistic Regression was used to calculate the adjusted Odds ratio with $95 \%$ CI.

\section{Results and discussion}

The study population included participants from urban and rural areas of 11 different districts of Karnataka. Udupi district had the maximum number of cases (52.7\%). Maximum numbers of cases (41\%) were in the age group of 51-60 years old followed by $34 \%$ in $41-50$ year age group (Fig. 1). Age of the participants ranged from $35-78$ years. Mean age of the study population was 53.2 years $( \pm 9.8)$. In case group, the age of cases ranged from 35-77 year with mean age of cases is $54.2( \pm 9.3)$. In control group the age of the participants ranged from 35-78 year. Mean age of the participants was $52.7( \pm 10)$. Similar study was done by Biswas et.al ${ }^{15}$ which included participants from the age range of 25-70 years. Also, a study done by Shields TL et.al ${ }^{24}$ included participants from the age range of 20-74 years. Table 1 shows the results of Univariate logistic regression for exposure variables education, marital status, habit of washing genitals, family history of cervical cancer, alcohol habit and diet. Habit of not washing genitals was found to be a risk factor of cervical cancer, but was not significant ( $p=0.073$ ). On the other hand, vaginal itching was a significant risk factor, which can be correlated with the findings of washing genitals. Similarly family history of cervical cancer was found to be significantly associated. When compared to vegetarians, people who consumed non-vegetarian diet were 2.260 (1.256-4.069) times more likely of getting cervical cancer. Education showed significant association with cervical cancer. People with primary education had an unadjusted odd ratio of $3.54(1.59-7.87)$ which was highly significant with p-value 0.002 . Also, illiteracy had unadjusted OR of 3.97 (1.85-8.54) with p-value of $<0.001$. Similar findings were reported in a study done by Franceschi $\mathrm{S}$ et.al ${ }^{14}$ in Chennai which showed OR of $1.4(0.7-2.8)$ for primary education and OR of 4.8 (2.7-8.4) for illiterate group when compared both with education level of high school and above. A study done by Taherian A et.al ${ }^{12}$ in Iran showed OR of $4.6(2.0-6.3, p=0.001)$ for uneducated when compared to educated group.

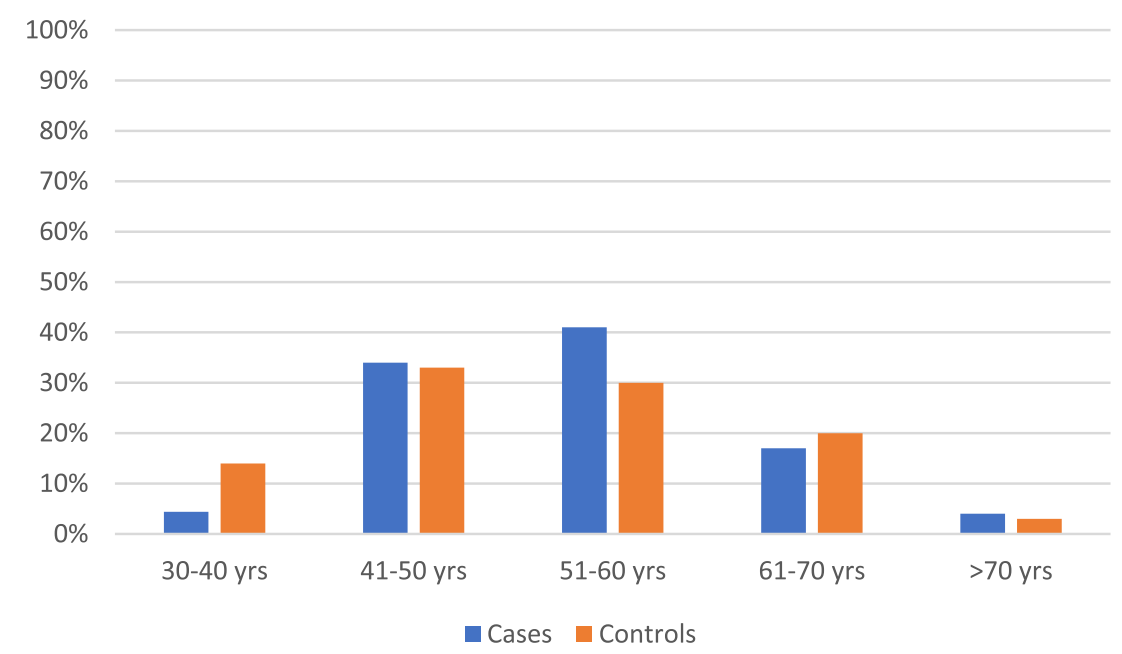

Fig. 1. Age distribution of cases and controls. 
Table 1

Univariate Logistic regression analysis for socio-demographic variables, habit and family history.

\begin{tabular}{|c|c|c|c|c|c|}
\hline Variables & Category & Cases $\mathrm{N}=91$ Frequency (\%) & $\begin{array}{l}\text { Controls = } 182 \text { Frequency } \\
(\%)\end{array}$ & Crude OR $(95 \% \mathrm{CI})$ & p-value \\
\hline \multirow[t]{3}{*}{ Education } & High School and above & $10(11.0)$ & $58(31.9)$ & Reference & \\
\hline & Primary education & $33(36.3)$ & $54(29.7)$ & $3.544(1.59-7.87)$ & $0.002^{*}$ \\
\hline & Illiterate & $48(52.7)$ & $70(38.5)$ & $3.977(1.85-8.54)$ & $<0.001^{* *}$ \\
\hline \multirow[t]{2}{*}{ Marital status } & Married & $76(83.5)$ & $141(77.5)$ & $1.473(0.766-2.833)$ & 0.10 \\
\hline & Widow & $15(16.5)$ & $41(22.5)$ & Reference & \\
\hline \multirow[t]{2}{*}{ Habit of washing genitals (after sexual intercourse) } & Yes & $23(25.8)$ & $67(36.8)$ & Reference & \\
\hline & No & $66(74.2)$ & $115(63.2)$ & $1.672(0.953-2.933)$ & 0.073 \\
\hline \multirow[t]{2}{*}{ Vaginal itching } & Yes & $30(33)$ & $23(12.6)$ & $3.515(1.891-6.534)$ & $<0.001^{* *}$ \\
\hline & No & $61(67)$ & $159(87.4)$ & Reference & \\
\hline \multirow[t]{2}{*}{ Family history of cervical cancer } & Yes & $27(29.7)$ & $6(3.3)$ & $\begin{array}{l}12.37(4.884- \\
31.356)\end{array}$ & $<0.001^{* *}$ \\
\hline & No & $64(70.3)$ & $176(96.7)$ & Reference & \\
\hline \multirow[t]{2}{*}{ Alcohol } & Yes & $13(14.3)$ & $8(4.4)$ & $3.625(1.44-9.00)$ & $0.006^{*}$ \\
\hline & No & $78(85.7)$ & $174(95.6)$ & Reference & \\
\hline \multirow[t]{2}{*}{ Diet } & Vegetarian & $19(20.9)$ & $68(37.4)$ & Reference & \\
\hline & Non- Vegetarian & $72(79.1)$ & $114(62.6)$ & $2.260(1.256-4.069)$ & $0.007^{*}$ \\
\hline
\end{tabular}

$\mathrm{p}<.05$.

$\mathrm{p} \leq 001$.

Table 2

Univariate Logistic regression analysis for menstrual factors.

\begin{tabular}{|c|c|c|c|c|c|}
\hline Variables & Category & Cases Frequency (\%) & Controls Frequency (\%) & Crude OR (95\% CI) & p-value \\
\hline \multirow[t]{3}{*}{ Age at menarche } & $<13$ year & $26(28.6)$ & $47(25.8)$ & $3.168(1.424-7.050)$ & $0.005^{*}$ \\
\hline & 13-14 year & $54(59.3)$ & $72(39.6)$ & $4.295(2.067-8.924)$ & $<0.001^{* *}$ \\
\hline & $>14$ year & $11(12.1)$ & $63(34.6)$ & Reference & \\
\hline \multirow[t]{2}{*}{ Vaginal itching } & Yes & $30(33)$ & $23(12.6)$ & $3.515(1.891-6.534)$ & $<0.001^{* *}$ \\
\hline & No & $61(67)$ & $159(87.4)$ & Reference & \\
\hline \multirow[t]{2}{*}{ Menopausal status } & Pre-menopausal & $9(9.9)$ & $52(29.1)$ & Reference & \\
\hline & Post- menopausal & $82(90.1)$ & $130(70.9)$ & $3.743(1.753-7.945)$ & $0.001^{* *}$ \\
\hline \multirow[t]{3}{*}{ Age at menopause } & Pre-menopausal & $9(9.9)$ & $52(29.1)$ & $.368(0.165-0.820)$ & $0.014^{*}$ \\
\hline & $<45$ & $42(46.2)$ & $45(24.7)$ & $1.983(1.128-3.483)$ & $0.017^{*}$ \\
\hline & $\geq 45$ & $40(44.0)$ & $85(46.7)$ & Reference & \\
\hline
\end{tabular}

$\mathrm{p}<.05$

$\mathrm{p} \leq 001$.

Table 2 shows the Univariate analysis for menstrual variables. Age at menarche and menopause were also significantly associated. Menopausal status was seen to be a risk factor for cervical cancer. A study done by Gyllensten $U$ et.al ${ }^{29}$ in Sweden to examine the value of screening for high-risk HPV in post-menopausal women showed that high-risk HPV were found in 6.2\% (95\% CI 5.2$7.3 \%$ ) of the menopausal women. Another similar study done by
Singh $\mathrm{B}$ and Nalini $\mathrm{N}^{30}$ in northern India-Jharkhand, found the incidence of cervical cancer in post-menopausal women to be $16 \%$. When compared, these two studies in different setting although shows different sets of data, there is a wide difference in the incidence which may be due to the difference in genetic, racial and geographical profile.

Table 3

Univariate Logistic regression analysis for reproductive and sexual factors.

\begin{tabular}{|c|c|c|c|c|c|}
\hline Variables & Category & Cases Frequency (\%) & Controls Frequency (\%) & Crude OR (95\% CI) & p-value \\
\hline \multirow[t]{2}{*}{ Vaginal itching } & Yes & $30(33)$ & $23(12.6)$ & $3.51(1.89-6.53)$ & $<0.001^{* *}$ \\
\hline & No & $61(67)$ & $159(87.4)$ & & \\
\hline \multirow[t]{2}{*}{ Age at 1st pregnancy } & $<18$ & $39(42.4)$ & $25(14.6)$ & $4.350(2.402-7.877)$ & $<0.001^{* *}$ \\
\hline & $\geq 18$ & $52(57.1)$ & $145(85.4)$ & Reference & \\
\hline \multirow[t]{2}{*}{ Abortion } & None & $61(67)$ & $163(89.6)$ & Reference & \\
\hline & At least one & $30(33)$ & $19(10.4)$ & $4.219(2.212-8.046)$ & $<0.001^{* *}$ \\
\hline \multirow[t]{2}{*}{ Age at 1 st coitus (in years) } & $<18$ & $66(72.5)$ & $43(23.6)$ & $8.534(4.810-15.142)$ & $<0.001^{* *}$ \\
\hline & $\geq 18$ & $25(27.5)$ & $139(76.4)$ & Reference & \\
\hline \multirow[t]{3}{*}{ Parity } & $<3$ & $8(8.8)$ & $70(38.5)$ & Reference & \\
\hline & $3-5$ & $40(44)$. & $75(41.2)$ & $4.667(2.043-10.66)$ & $<0.001^{* *}$ \\
\hline & $\geq 6$ & $43(47.3)$ & $37(20.3)$ & $10.169(4.332-23.872)$ & $<0.001^{* *}$ \\
\hline \multirow[t]{2}{*}{ Permanent methods } & Yes & $72(79.1)$ & $117(64.3)$ & $2.105(1.168-3.796)$ & $0.013^{*}$ \\
\hline & No & 19 (20.9) & $65(35.7)$ & Reference & \\
\hline \multirow[t]{2}{*}{ Latency period (current age - age at 1st coitus) } & $<30$ & $22(24.2)$ & $91(50)$ & Reference & \\
\hline & $\geq 30$ & $69(75.8)$ & $91(50)$ & $3.136(1.424-7.050)$ & $<0.001^{* *}$ \\
\hline \multirow[t]{2}{*}{ No of sexual partners } & 1 & $87(95.5)$ & $180(98.9)$ & Reference & \\
\hline & $>1$ & $4(4.5)$ & $2(1.1)$ & $4.286(0.770-23.863)$ & 0.097 \\
\hline
\end{tabular}

${ }^{* *} \mathrm{p}<.05$ 
Table 4

Multivariate logistic regression.

\begin{tabular}{|c|c|c|c|c|c|c|}
\hline Variables & Groups & Cases N (\%) & Controls N (\%) & Unadjusted OR (95\% CI) & Adjusted OR(95\% CI) & $P$ value \\
\hline \multirow[t]{2}{*}{ Marital status } & Married & $76(83.5)$ & $141(77.5)$ & $1.473(.76-2.83)$ & $2.98(1.23-7.20)$ & 0.015 \\
\hline & Widow & $15(16.5)$ & $41(22.5)$ & 1 & 1 & \\
\hline \multirow[t]{2}{*}{ Habit of washing genitals (after sexual intercourse) } & Yes & $23(25.8)$ & $67(36.8)$ & 1 & 1 & \\
\hline & No & $66(74.2)$ & $115(63.2)$ & $1.672(0.95-2.93)$ & $2.064(0.98-4.34)$ & 0.056 \\
\hline \multirow[t]{2}{*}{ History of alcohol use } & Yes & $13(14.3)$ & $8(4.4)$ & $3.625(1.44-9.00)$ & 4.55 (1.17-17.73) & 0.02 \\
\hline & No & $78(85.7)$ & $174(95.6)$ & 1 & & \\
\hline \multirow[t]{3}{*}{ Age at menarche } & $<13$ year & $26(28.6)$ & $47(25.8)$ & $3.168(1.42-7.05)$ & $1.51(0.55-4.13)$ & 0.414 \\
\hline & 13-14 year & $54(59.3)$ & $72(39.6)$ & $4.295(2.06-8.92)$ & $2.91(1.18-7.20)$ & 0.020 \\
\hline & $>14$ year & $11(12.1)$ & $63(34.6)$ & 1 & 1 & \\
\hline \multirow[t]{3}{*}{ Age at menopause } & Pre-menopausal & $9(9.9)$ & $52(29.1)$ & $3.68(0.165-0.820)$ & $0.41(0.14-1.14)$ & 0.088 \\
\hline & $<45$ & $42(46.2)$ & $45(24.7)$ & $1.98(1.12-3.48)$ & $1.22(.57-2.62)$ & 0.594 \\
\hline & $\geq 45$ & $40(44.0)$ & $85(46.7)$ & 1 & & \\
\hline \multirow[t]{2}{*}{ Vaginal itching } & Yes & $30(33)$ & $23(12.6)$ & $3.51(1.89-6.53)$ & $4.00(1.72-9.30)$ & $<\mathbf{0 . 0 0 1}$ \\
\hline & No & $61(67)$ & $159(87.4)$ & 1 & 1 & \\
\hline \multirow[t]{2}{*}{ Age at 1 st coitus (in years) } & $<18$ & $66(72.5)$ & $43(23.6)$ & $8.53(4.81-15.14)$ & $5.44(2.73-10.86)$ & $<\mathbf{0 . 0 0 1}$ \\
\hline & $\geq 18$ & $25(27.5)$ & $139(76.4)$ & 1 & & \\
\hline \multirow[t]{2}{*}{ Abortion } & None & $61(67)$ & $163(89.6)$ & 1 & 1 & \\
\hline & At least one & $30(33)$ & $19(10.4)$ & $4.21(2.21-8.04)$ & $2.61(1.07-6.38)$ & 0.035 \\
\hline \multirow[t]{3}{*}{ Parity } & $<3$ & $8(8.8)$ & $70(38.5)$ & 1 & & \\
\hline & $3-5$ & $40(44)$ & $75(41.2)$ & $4.667(2.043-10.66)$ & 3.16 (1.12-8.91) & 0.029 \\
\hline & $\geq 6$ & $43(47.2)$ & $37(20.3)$ & $10.169(4.332-23.872)$ & $5.57(1.70-18.16)$ & 0.004 \\
\hline
\end{tabular}

p-value $<0.05=$ significant.

Bold values show statistically significant odds ratio.

Table 3 shows Univariate analysis for sexual and reproductive factors. Latency period which is calculated by subtracting current age with age at first coitus was seen to be significantly associated with cervical cancer. No. of sexual partners was not a significant risk factor in this study. Table 4 shows Multiple Logistic Regression analysis for risk factors of cervical cancer. Age at first coitus of $<18$ years showed high significance $(\mathrm{p}=<0.001)$ with cervical cancer with OR of 5.44 (2.73-10.86). Similar findings were observed in a study by Biswas $\mathrm{N}$ et.al ${ }^{15}$ which showed OR of 2.7 $(0.8-8.9)$ with $\mathrm{p}=0.005$ for age at 1 st coitus of $<18$ years. Parity was significantly associated with risk of cervical cancer. A study done by Franceschi et.al ${ }^{14}$ in Chennai showed similar findings for high parity ( $>4$ vs. $<2$ births) $\mathrm{OR}=7.3$ and for $\geq 3$ vs. $<3$ births $\mathrm{OR}=3.01$, but was insignificant. Biswas L. et.al ${ }^{15}$ also showed similar findings with $\mathrm{OR}=1.6$ for parity of $>3(\mathrm{p}=0.06)$ and was significant. Age at menarche also had significant association with risk of cervical cancer. The adjusted odds ratio for age at menarche for $<13$ years was $1.51(.55-4.13, p=.414)$ and or $13-14$ years was $2.90(1.18-7.20, \mathrm{p}=.020)$ when compared to age at menarche of $>14$ years. In a study done by Reis $\mathrm{N}^{20}$ in turkey, they showed a significant association between age at menarche and cervical cancer in chi square analysis. $(\mathrm{p}=0.001)$.

\section{Conclusion}

Marital status (married), age at menarche of 13-14 years, history of vaginal itching, age at 1 st coitus of $<18$ years, at least one abortion, parity of $>3$ are important risk factors of cervical cancer in this study. Health education can be given along with regular cervical cancer screening to women - especially post-menopausal women, and early and regular screening for women in reproductive age group; it will help in early diagnosis and prompt treatment. Introduction of HPV vaccination starting at early adolescent age group should be geared up in the public facilities as age at coitus $<18$ years is a risk factor. Focussed health programmes should be initiated to raise awareness to increase the informed health seeking behaviour in the high-risk group.

\section{Limitations}

The sample size was not enough to conclude many factors such as mode of delivery, OCP use, family history of cervical cancer etc.
Interviewer bias may be a limitation. Recall bias may be a problem. The study population is not a representative of general population, so the findings cannot be generalised.

\section{Conflict of interest}

None.

\section{Acknowledgement}

The authors gratefully acknowledge all the support extended by Head of the Department of Oncology and Radiology, Obstetrics and Gynaecology and Medical Superintendent Kasturba Hospital. Authors would also like to thank the Shirdi Sai Baba hospital staff for their cooperation.

\section{References}

1. Cancer Mortality, The Global Burden ofdisease 2004 Update, World Health Organisation. Available from: http://www.who.int/healthinfo/ globalburdendiseace/globalHealthRisks report full.Pdf. (Accessed 14 December 2012).

2. Disease incidence, prevalence and disability, The global burden burden ofdisease 2004 update, World Health Organisation. Available from: http:// www.who.int/healthinfo/globalburdendisease/GBDreport20043.pdf. (Accessed 14 December 2012).

3. Gupta S, Rao YN, Agarwal SP. Emerging strategies for cancer control for women in India. 50 years of Cancer control in India. Available from: http://www.medindia. net/education/MinistryofHealth/pg192to203.pdf. (Accessed 14 December 2012).

4. Institute for Health Metrics and Evaluation. The Challenge Ahead: Progress in Breast and Cervical Cancer. Institute of Health Metrics and Evaluation. 2011. Available from: http://www.healthmetricsandevaluation.org/publications/ policyreport/challenge-ahead-progress-and-setbacksbreastand-cervicalcancer. (Accessed 24 September 2017).

5. Rao YN, Gupta S, Agarwal SP. National cancer control programme: Current status and strategies, 50 years of Cancer control in India. Available from: http://www. medindia.net/education/MinistryofHealth/pg192to203.pdf. (Accessed 21 February 2013).

6. Available from: http://webmail.medindia.net/education/Ministryofhealth/ pg49to55.pdf. (Accessed 04 April 2013).

7. Task force Reports for 11th five year plan2007-12. National Cancer Control Programme, March 2008.

8. Jagnnath GV, Hiremath SS. Oral Cancer Prevalence and assessment of various risk factors among Oral cancer patients attending Kidwai Memorial Institute of Oncology. An epidemiological study. Available from: http://119.82.96.198:8080/ jspui/bitstream/123456789/2652/1/Jagannatha\%20G\%20V.pdf. (Accessed 28 June 2013). 
9. Reddy KR. Department of Epidemiology and Statistics, Bangalore cancer registry. Kidwai Memorial Institute of Oncology. Available from: http://kidwai.kar.nic.in/ statistics.htm. (Accessed 28 June 2013).

10. Cancer statistics in Indian women, The Times of India. 2012, 21st October 05.55AM IST.

11. Senapathy J, Umadevi P, Kannika PS. The present scenario of cervical cancer control and hpv epidemiology in India: an outline. Asian Pacific J Cancer Prev. 2011;12:1107-1115.

12. Taherin A, Fatahi E, Soleimani B. A study of risk factors for cervical cancer: a case control study in Isfahan- Iran. Kuwait Med J. 2002;34(2):128-213.

13. Smith JS, Green J, de Gonzalez A. Cervical cancer and use of hormonal contraceptives. A systematic review. Lancet. 2003;361:1159-1167.

14. Franceschi S, Rajkumar T, Vaccerella S, Gajalakshmi V, Sharmila A, Snijders P, et al. Human papilloma virus and risk factors for cervical cancer in Chennai, India: a case-control study. Int J Cancer. 2003;107:127-133.

15. Biswas LN, Manna B, Maiti PK, Sengupta S. Sexual risk factors for cervical cancer among rural Indian women: a case-control study. Int J Epidemiol. 1997;26:491-495.

16. Thulaseedharan JV, Malila N, Hakama M. Socio demographic and reproductive risk factors for cervical cancer -a large prospective cohort study from rural India. Asian Pacific J Cancer Prev. 2012;13:2991-2995.

17. Chichareon S, Herrero R, Munoz N, Bosch F, Jacob M, Daecon J, et al. Risk factors for cervical cancer in Thailand: a case-control study. J Natl Cancer Inst. 1998;90 (1).

18. Nascimento M, Silva G, Monteiro G. History of performing Pap smears and cervical cancer: case-control study in the Baixada Fluminense, Rio de Janeiro, Brazil. J Public Health. 2012;28(10):1841-1853.

19. Stefani E, Acosta G, Pellegrini H, Ronco A, Mendilaharsu M, Lando G, et al Dietary patterns and risk of cervical cancer: a case-control study in Uruguay. Open J Obstetr Gynaecol. 2011;1:25-30.

20. Reis N, Beji NK, Kilic D. Risk factors for cervical cancer: results from a hospitalbased case-control study. Int J Hematol Oncol. 2011;3(21).
21. Plummer M, Herrero R, Franceschi S, Meijer C, Snijders P, Bosch F, Sanjose S, Mun N. Smoking and cervical cancer: pooled analysis of the IARC multi-centric case-control study. Cancer Causes Control. 2003;14:805-814.

22. Moreno V, Bosch F, Munoz N, Meijer CJ, Shah KV, Walboomers JM, et al. Effect of oral contraceptives on risk of cervical cancer in women with human papilloma virus infection: the IARC multicentric case control study. Lancet. 2002;359:1085-1192.

23. Castellsagué X, Diaz M, Vaccarela S, Sanjose S, Munoz N, Herrero R, et al. Intrauterine device use, cervical infection with human papilloma virus, and risk of cervical cancer: a pooled analysis of 26 epidemiological studies. Lancet Oncol. 2011;12(11):1023-1031.

24. Shields TS, Brinton LA, Burk R, Wang S, Winsten S, Ziegler R, et al. A casecontrol study of risk factors for invasive cervical cancer among U.S. women exposed to oncogenic types of human papillomavirus. Cancer Epidemiol Biomarkers Prev. 2004;13:1574-1582.

25. Jones CJ, Brinimi LA, Hamm RF, Stolley P, Lehman H, Levine R, et al. Risk factors for in situ cervical cancer: results from a case-control study. Cancer Res. 1990;50:3657-3662.

26. Parazzini F, Vecchia CL, Negri E, Franceschi S, Moroni S, Chatenoud L, et al. Case-control study of oestrogen replacement therapy and risk of cervical cancer. BMJ. 1997;315:85.

27. Daling JR, Madeleine MM, McKnight B. The relationship of human papilloma virus related cervical tumours to cigarette smoking, oral contraceptive use, and prior herpes simplex virus type 2 infections. Epidemiol Biomarkers Prev. 1996;5:541-548.

28. Raychaudhuri S, Mandal S. Socio-demographic and behavioural risk factors for cervical cancer and knowledge attitude and practice in rural and urban areas of North Bengal, India. Asian Pacific J Cancer Prev. 2012;13:1093-1096.

29. Gyllensten U, Gustavsson I, Lindell M, Wilander E. Primary high-risk HPV screening for cervical cancer in post-menopausal women. Gynecol Oncol. 2012;125(2):343-345.

30. Singh B. Nalini N. Study of incidence and different aspects of cervical malignancy in tertiary centre of Jharkhand, India. Int J Reproduct Contracept Obstetr Gynecol. 2017;6(7):3118. 